\title{
Pengaruh Pemberian Lemna Minor Terhadap Produksi Susu Harian Dan 4\% FCM Susu Sapi Perah Friesian Holstein
}

(The Influence of Lemna Minor on Daily Milk Production and 4\% FCM of Friesian Holstein Cow)

\author{
Raden Febrianto Christi dan U Hidayat Tanuwiria \\ Fakultas Peternakan Universitas Padjadjaran Sumedang \\ Email :radenfebrianto92@gmail.com
}

\begin{abstract}
Intisari
Sapi perah merupakan salah satu penghasil protein hewani, yang dalam pemeliharaannya selalu diarahkan pada peningkatan produksi susu. Tujuan Penelitian mengetahui pengaruh pemberian lemna minor terhadap produksi susu harian dan 4\% FCM susu sapi perah friesien holstein. Ternak yang digunakan pada penelitian adalah Sapi FH laktasi kedua sampai empat bulan sebanyak 20 ekor ternak dengan bobot 400-500 kg, yang berada di Kelompok Peternak Sapi Perah Kp Tanggung Renteng Desa Pamegatan Kecamatan Cikajang Kabupaten Garut Provinsi Jawa Barat kemudian dipelihara selama 60 hari dan diberikan pakan sesuai dengan perlakuan yaitu R0= Rumput $60 \%+$ Konsentrat $40 \%$, R1= Rumput 50\% + Konsentrat 40\% + Lemna basah 10\%, R2= Rumput 60\% + Konsentrat 37\% + Lemna Kering $3 \%$, R3 $=$ Rumput 50\% + Konsentrat 37\% + Lemna Basah 10\% + 3\% Lemna Kering, R4= Rumput 45\% + Konsentrat 38\% + lemna basah 15\% + Lemna Kering 2\%. Hasil penelitian menunjukkan bahwa pengaruh pemberian lemna minor berpengaruh terhadap produksi dengan perlakuan R3 memberikan hasil yang paling baik.
\end{abstract}

Kata Kunci :Lemna minor, produksi susu harian, 4\% FCM, sapi perah FH

\begin{abstract}
Dairy cows are one of a producer of animal protein, which is purposed to increase the milk production. The aim of this study was to reveal the effect of lemna minor in ration on the daily milk production and $4 \%$ FCM of Friesien Holstein (FH) cows. The animals used in the experiment were 20 second lactation of FH cows weighing 400-500 kg. The study was done in the Kp Deng Renteng, Cikajang District, Garut Regency, West Java Province for 60 days. The treatments in this experiment were R $0=60 \%$ Grass $+40 \%$ Concentrate, R1 $=50 \%$ Grass $+40 \%$ Concentrate $+10 \%$ wet Lemna, R2 $=60 \%$ Grass $+37 \%$ Concentrate + $3 \%$ Dry Lemna, R3 $=50 \%$ Grass $+37 \%$ Concentrate $+10 \%$ Wet Lemna $+3 \%$ Dry Lemna, R4 $=$ Grass $45 \%$ $+38 \%$ Concentrate $+15 \%$ Wet Lemna $+2 \%$ Dry Lemna. The results of this experiment showed that the effect of lemna minor in ration affected on the milk production and treatment R3 provided the best results.
\end{abstract}

Keywords: Lemna minor, daily milk production, 4\% FCM, FH dairy cows

\section{Pendahuluan}

Peternakan merupakan salah satu subsektor pertanian yang memiliki peran strategis dalam memenuhi kebutuhan pangan, peningkatan lapangan pekerjaan, dan peningkatan pendapatan penduduk. Peternakan juga memiliki peran penting dalam pemenuhan gizi bangsa Indonesia. Hasil peternakan berupa susu, telur dan daging merupakan bahan makanan yang memiliki kandungan zat-zat gizi yang penting bagi tubuh. Sapi perah merupakan salah satu penghasil protein hewani, yang dalam pemeliharaannya 
selalu diarahkan pada peningkatan produksi susu. Sapi perah bangsa Fries Holland (FH) merupakan bangsa sapi perah yang memiliki produksi susu paling tinggi diantara bangsa sapi yang lain. Produksi susu sapi perah FH di negara asalnya mencapai $6.000-8.000$ $\mathrm{kg} /$ ekor/laktasi, di Inggris sekitar 35\% dari total populasi sapi perah dapat mencapai $8069 \mathrm{~kg} /$ ekor/laktasi (Arbel dkk.,2001) dalam Tawaf, 2009). Produksi susu yang dihasilkan oleh sapi perah FH di Indonesia ternyata lebih rendah, berkisar antara 3.000-4.000 liter per laktasi. Produksi rata-rata sapi perah di Indonesia hanya mencapai 10,7 liter per ekor per hari (3.264 liter per laktasi) (Chalid, 2006 dalam Tawaf, 2009).

Kemampuan memproduksi susu seekor sapi perah baik kualitas maupun kuantitas sangat dipengaruhi berbagai faktor genetik dan lingkungan. Faktor genetik berpengaruh $30 \%$ pada produksi susu sedangkan lingkungan berpengaruh sebesar 70\%. Faktor lingkungan yang paling berpengaruh yaitu manajemen pemeliharaan, pakan, temperatur, kesehatan dan manajemen reproduksi. Salah satu usaha untuk meningkatkan produktivitas sapi perah melalui perbaikan pemberian pakan yaitu dengan pemberian hijauan yang berkualitas tinggi dan harga yang murah.

Lemna minor adalah tanaman air yang tumbuh mengapung bebas dengan tingkat penyebaran yang sangat luas dan potensial sebagai sumber hijauan pakan bagi ternak yang berkualitas tinggi dengan berkembang biak secara vegetatif atau tunas (Kittiwongwattana dan Vuttipongchaikij, 2013). Daun tanaman lemna berbentuk oval dengan ukuran kecil dan akar menggantung dengan panjang sekitar $1 \mathrm{~cm}$. Sistem perakaran yang menggantung sangat memungkinkan memiliki kemampuan menyerap zat organik dan anorganik yang ada di perairan, sehingga tanaman lemna sering dimanfaatkan untuk remediasi perairan. Produktivitas biomasa $L$ minor sekitar $176,38 \mathrm{~g} / \mathrm{m}^{2}$ dalam keadaan basah atau $6,24 \mathrm{~g} / \mathrm{m}^{2}$ dalam keadaan kering (Nopriani et al., 2014). Produktivitas tanaman $L$ minor. cukup tinggi, yaitu mampu memproduksi 10-30 ton bahan kering ha-1 tahun1 dengan kandungan $43 \%$ protein kasar (Leng et al., 1995). Potensi pemanfaatan $L$ minor untuk bahan pakan didukung oleh kandungan protein yang berkisar antara $29,3 \%-38 \%$, serat kasarnya $13,5 \%$, dan lemak kasar 4,9\% (Hassan dan Edward, 1992). Pemberian lemna minor dengan kondisi kering dan basah atau bahkan campuran keduanya terhadap sapi perah diharapkan dapat meningkatkan produksi susu. Pemberian pellet daun pelepah sawit sebanyak $30 \%$ pada sapi perah dapat menghasilkan produksi susu sekitar 366 liter/28hari (Abu Bakar et al. 2001). Dilaporkan Sukarini (2006) bahwa pemberian hijauan dan konsentrat dapat meningkatkan produksi susu pada kambing dan sapi perah. Berdasarkan latar belakang yang telah diuraikan maka perlu dilakukan penelitian Pemberian lemna minor Terhadap Produksi Susu Harian dan 4\% FCM Susu Sapi Perah Friesien Holstein. 


\section{Metode Penelitian}

Penelitian in vivo telah dilaksanakan pada bulan April-Juni 2017 di Kelompok Peternak Sapi Perah Kp. Tanggung Renteng Desa Pamegatan Kecamatan Cikajang Kabupaten Garut Provinsi Jawa Barat. Ternak yang digunakan pada penelitian adalah Sapi FH laktasi kedua sampai empat bulan sebanyak 20 ekor ternak dengan bobot 400-500 kg, yang berada di Kelompok Peternak Sapi Perah Kp Tanggung Renteng Desa Pamegatan Kecamatan Cikajang Kabupaten Garut Provinsi Jawa Barat kemudian dipelihara selama 60 hari dan diberikan pakan sesuai dengan perlakuan yaitu $\mathrm{R} 0=$ Rumput $60 \%+$ Konsentrat $40 \%$, R1 $=$ Rumput $50 \%+$ Konsentrat $40 \%$ + Lemna basah $10 \%$, R2= Rumput $60 \%$ + Konsentrat $37 \%$ + Lemna Kering 3\%, R3= Rumput $50 \%$ + Konsentrat 37\% + Lemna Basah $10 \%+3 \%$ Lemna Kering, R4= Rumput $45 \%$ + Konsentrat 38\% + lemna basah $15 \%+$ Lemna Kering 2\%. Ternak sapi FH laktasi melalui tahapan penyesuaian terhadap perubahan pakan (pre-eliminary) selama dua minggu sebelum diberikan perlakuan. Tahap ini bertujuan untuk mengurangi pengaruh pakan yang diberikan selama perlakuan terhadap peubah yang diamati. Persiapan pemeliharaan meliputi pembersihan kandang, menentukkan ternak sapi FH laktasi yang akan dijadikan sebagai ternak penelitian dan persiapan pakan. Pakan hijauan berupa rumput lapang yaitu rumput gajah mott dan limbah hasil pertanian berupa daun wortel dan daun kubis. Konsentrat yang diberikan adalah konsentrat yang berasal dari KPGS. Pemberian pakan sebanyak \pm $3 \%$ dari perkiraan bobot hidup dan penghitungan kebutuhan gizi pakan mengacu pada petunjuk Nutrient Requirements of Dairy Cattle (NRC, 2001). Pakan diberikan tiga kali sehari yaitu pagi pukul 07.00 WIB, Siang pukul 13.00 dan sore pukul 16.00 WIB kecuali pemberian konsentrat hanya dua kali pemberiannya. Pemberian air minum disediakan adlibitum. Konsumsi pakan dan sisa pakan ditimbang setiap hari. Produksi susu per hari diukur dengan mencatat hasil pemerahan pada pagi dan sore hari. Sampel susu diambil pada awal penelitian (sebelum perlakuan), awal perlakuan (hari ke-1 perlakuan), pertengahan perlakuan (hari ke-3 perlakuan) dan akhir penelitian (setelah 7 hari perlakuan) untuk uji kualitas susu.

\section{Hasil dan Pembahasan}

\section{Produksi Susu Harian}

Susu merupakan suatu bahan makanan alami yang mendekati sempurna dengan kandungan protein, mineral dan vitamin yang tinggi, sehingga menjadikan susu sebagai sumber bahan makanan yang essensial (Blakely dan Bade, 1994). Produktivitas ternak perah yang baik dapat dilihat dari salah satu kriteria diantaranya adalah dengan mengetahui jumlah produksi susu. Produktivitas ternak sangat erat kaitanya dengan kualitas pakan. Kualitas pakan yang baik akan menghasilkan peningkatan dalam produksi susu. Hasil pengukuran 
produksi susu disajikan pada Tabel 1 yang diukur berdasarkan hasil dari Tabel 1. Pengaruh Perlakuan Terhadap Produksi Susu Harian

\begin{tabular}{|c|c|c|c|c|c|}
\hline & R0 & R1 & R2 & R3 & R4 \\
\hline & \multicolumn{5}{|c|}{ 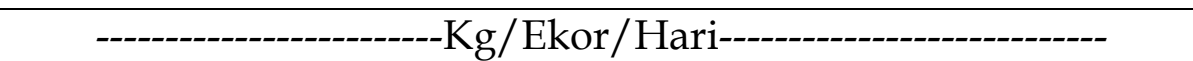 } \\
\hline 1 & 7,44 & 9,18 & 11,37 & 12,41 & 11,69 \\
\hline 2 & 14,50 & 14,35 & 13,47 & 13,29 & 14,07 \\
\hline 3 & 14,92 & 12,91 & 13,30 & 15,80 & 11,75 \\
\hline 4 & 20,35 & 14,85 & 13,07 & 15,68 & 21,81 \\
\hline Jumlah & 57,21 & 51,29 & 51,21 & 57,18 & 59,32 \\
\hline Uji Duncan & $14,30^{\mathrm{b}}$ & $12,82^{b}$ & $12,80^{\mathrm{b}}$ & $14,29 \mathrm{~b}$ & $14,83^{\mathrm{a}}$ \\
\hline
\end{tabular}

Keterangan : Huruf yang berbeda dalam kolom signifikansi menunjukan berbeda nyata $(\mathrm{P}<0,05)$

penjumlahan produksi susu pada pemerahan pagi dan sore. Berdasarkan Tabel 1. terlihat bahwa rataan produksi susu tertinggi dicapai pada sapi yang mendapat perlakuan R4 yaitu 14,83 $\mathrm{kg} / \mathrm{ekor} / \mathrm{hari}$, sedangkan produksi susu terendah dicapai pada sapi yang mendapatkan perlakuan R2 yaitu 12,80 kg/ekor/hari. Menurut Ensminger dan Howard (2006) bahwa sapi FH yang normal menghasilkan produksi susu sebesar 12,498 Kg. Melihat hasil data yang disajikan pada Tabel 1. menunjukkan bahwa produksi susu rata-rata berada pada kisaran yang lebih dari pada umumnya.

Hasil analisis sidik ragam menunjukkan bahwa terdapat perbedaan yang nyata $(\mathrm{P}<0,05)$ terhadap jumlah produksi susu. Setelah dilakukan uji jarak berganda Duncan adanya perbedaan hasil antara R4 dengan perlakuan R0, R1, R2, dan R3. Hal ini menunjukkan adanya pengaruh perlakuan yang diberikan sehingga memberikan dampak langsung pada jumlah produksi susu yang dihasilkan yaitu pemberian lemna basah sebanyak $15 \%$ dan lemna kering 2\%. Walaupun hasil analisis uji duncan menunjukkan persamaan antara perlakuan R0 dengan R1, R2, dan R3 tetapi secara pengukuran produksi terdapat adanya perbedaan jumlah produksi susu. Hal tersebut diduga bahwa pemberian lemna minor dalam campuran ransum berpengaruh terhadap produksi susu. Menurut Owen (1979) menyatakan bahwa dalam penyusunan ransum hal yang harus diperhatikan adalah kandungan nutrien dan susunannya yang akan diberikan pada ternak.

Protein yang terkandung dalam konsentrat dan lemna minor akan didegradasi dalam rumen oleh mikroba rumen menjadi protein mikroba. Protein mikroba bersama-sama protein pakan yang tidak dapat didegradasi yang masuk dalam usus halus akan dihidrolisis menjadi asam amino lalu diserap dan masuk dalam sistem peredaran darah, sebagian masuk dalam sel alveoli bersama dengan bahan yang lainnya kemudian terjadi sintesis air susu (Soeharsono, 2008). Sementara itu rendahnya serat kasar pada konsentrat dan rumput yang dikurangi membuat adanya peningkatan kandungan bahan ekstrak tanpa nitrogen secara proporsional. Anggorodi (1994) 
mengatakan apabila kandungan serat kasar rendah maka kandungan BETN akan meningkat. Komponen BETN kaya akan pati, gula, bagian serat kasar yang tidak larut oleh eter dan bahan-bahan organik cair (Crampton dan Lloyd, 1959). Daya cerna komponen BETN lebih tinggi dibandingkan dengan daya cerna serat kasar (Anggorodi, 1994). BETN dalam konsentrat akan mudah dirombak menjadi asam lemak terbang yang digunakan sebagai sumber glukosa bagi pembentukan susu.

Sukarini (2006) menyatakan bahwa penggunaan konsentrat dalam ransum selain menyuplai protein terlarut, juga mengandung BETN yang tinggi dengan serat kasar rendah yang dimaksudkan untuk mendorong pembentukan asam propionat oleh bakteri rumen sebagai bahan baku glikogen bagi induk ternak dan sumber glukosa untuk bahan baku sintesis air susu.

\section{Produksi Susu 4\% FCM}

Sapi perah yang baik adalah ternak dengan jumlah produksi susu yang tinggi dan distandardisasi 4\% FCM (Fat Corrected Milk). Hasil pengukuran produksi susu 4\% FCM disajikan pada Tabel 2 yang diukur berdasarkan perhitungan rumus yang telah ditentukan.

Tabel 2. Pengaruh Perlakuan Terhadap Produksi Susu 4\% FCM

\begin{tabular}{cccccc}
\hline & R0 & R1 & R2 & R3 & R4 \\
\hline 1 & ---- & 8,99 & 12,44 & 12,75 & 11,23 \\
2 & 7,04 & 15,15 & 13,55 & 13,41 & 15,64 \\
3 & 16,60 & 13,36 & 14,01 & 16,55 & 10,75 \\
4 & 14,22 & 14,64 & 11,79 & 18,55 & 23,21 \\
\hline Jumlah & 20,79 & 52,14 & 51,79 & 61,26 & 60,83 \\
Uji Duncan & $14,66^{\mathrm{b}}$ & $13,03^{\mathrm{b}}$ & $12,94^{\mathrm{b}}$ & $15,31^{\mathrm{a}}$ & $15,20^{\mathrm{ab}}$ \\
\hline
\end{tabular}

Keterangan : Huruf yang berbeda dalam kolom signifikansi menunjukan berbeda nyata $(\mathrm{P}<0,05)$

Berdasarkan Tabel 2. menunjukan bahwa perlakuan R3 dan R4 dapat meningkatkan produksi susu yang dikoreksi 4\% FCM sedangkan perlakuan R1 dan R2 menunjukan penurunan. Perlakuan memberi hasil 14,66 Kg untuk R0; 13,03 untuk R1; 12,94 untuk R2; 15,31 untuk R3 dan 15,20 R4. Hal ini karena produksi susu dipengaruhi oleh faktor lingkungan terutama pakan memegang peranan penting terhadap proses fisiologis dalam tubuh sapi perah sehingga pada gilirannya mempengaruhi produksi susu.

Hasil sidik ragam (Tabel 2) menyatakan bahwa perlakuan berpengaruh nyata $(\mathrm{P}<0,05)$ terhadap produksi susu 4\% FCM. Penurunan produksi susu pada perlakuan R1 dan R2 lebih dikarenakan faktor pemberian pakan. Ransum R1 dengan penambahan lemna basah $10 \%$ tidak mampu memberikan peningkatan yang nyata begitu juga dengan R2 dengan 
penambahan lemna kering 3\%. Hal tersebut karena jumlah sumbangan protein sangat kecil sehingga tidak terjadi peningkatan yang nyata. Di sisi lain karena adanya perbedaan jumlah pemberian hijauan yang diberikan pada ternak. Kadar lemak yang dihasilkan perlakuan R1 (Tabel 5) ini nilainya paling rendah dibandingkan dengan perlakuan yang lain. Hal ini dikarenakan formulasi pakan yang terdiri rumput $50 \%$, konsentrat $40 \%$, dan lemna basah $10 \%$ menunjukan imbangan yang tidak biasa diberikan pada ternak. Jika dibandingkan dengan perlakuan yang lain seperti R2. Kandungan Kadar lemak susu dipengaruhi oleh konsumsi sapi perah terhadap pakan sumber serat kasar (Anggorodi, 1994). Kadar lemak susu berasal dari serat kasar yang dicerna dirumen. Akibatnya, hasil perhitungan lebih lanjut antara produksi dan kadar lemak menampakkan bahwa produksi susu yang distandarisasi ke 4\% FCM juga meningkat. Rumput dan lemna minor merupakan pakan sumber serat. Serat yang tinggi dalam pakan sapi akan meningkatkan persentase lemak lebih tinggi dibandingkan dengan pemberian konsentrat (Sulaeman dkk., 2014).

\section{Kesimpulan}

Hasil penelitian menunjukkan bahwa pengaruh pemberian lemna minor berpengaruh terhadap produksi dengan perlakuan R3 memberikan hasil yang paling baik.

\section{Daftar Pustaka}

Abu Bakar C, Yusof SM, Hayakawa H, Zahari MW, Sukri IM, Shukri I. 2001. Lactations responses of graded Shahiwal-Friesians fed pelleted OPF as complete feed. Proc. 23 d MSAP Ann. Conf., Langkawi, Malaysia.

Anggorodi. 1994. Ilmu Makanan Ternak Umum. Penerbit Gramedia. Jakarta.

Arbel. 2001. Manajemen Produksi dan Operasi Sapi Perah. Lembaga Penerbit Universitas Indonesia. Jakarta.

Atmaja, S. 2011. Kasus Kesmavet.http://www.docstoc.co $\mathrm{m} /$ docs//KasusKesmavet//.

Diakses pada tanggal12 Mei 2011.

Asminaya, N. S. 2007. Peggunaan Ransum Komplit Berbasis Sampah Sayuran Pasar Untuk Produksi dan Komposisi Susu Kambing Perah. Fakultas Peternakan. Institut Pertanian Bogor, Bogor.

Blakely, J. dan H. Bade. 1994. Ilmu Peternakan. Edisi Keempat. Gajah Mada University Press. Yogyakarta.

Crampton, E.W., and L.E. Lloyd. 1959. Fundamental of Nutrition. San Fransisco,,W.H. Freeman and Company. pp $216-231$.

Eckles, H. \& L. Anthony. 1956. Dairy Cattle and Milk Production. Edisi Kelima. The Macmillan Co., New York.

Eckles CH, Coms WR, Macy H. 1984. Milk and Milk Product Ed ke-4. Denvile Illinois: The Mac Graw Hill Publisher Inch.

Ensminger,M. E.1993. Diary Cattle Science. 3rd Ed.,The Interstate 
Publisher, Inc. Danville, United State of America.

Ensminger, M. E and D. T. Howard. 2006. Dairy Cattle Science. 4th Ed. The Interstate Printers and Publisher, Inc. Danville.

Fardiaz, S., 1989. Mikrobiologi Pangan. Direktorat Jenderal Pendidikan Tinggi Pusat Antar Universitas IPB, Bogor.

Girisonta. 1995. Petunjuk Beternak Sapi Perah. Kanisius : Yogyakarta

Hassan, M.S and Edwards, P. 1992. Evaluation of duckweed (Lemna perpusilla and Spirodela polyrhiza) as feed for Nile Tilapia (Oreochromis niloticus).

Aquaculture, 104: 315-326.

Jay, J.M. 2000. Modern Food Microbiology Sixth Edition. Maryland: Aspen Publishers.

Kittiwongwattana, C and S Vuttipongchaikij. 2013. Effect of nutrient media on vegetative growth of Lemna minor and Landoltia punctata during in vitro and ex vitro cultivation. Maejo International J of Sci and Technol. 7(01):60-69.

Larson, B. L. 1985. Biosynthesis and Cellular Secretion of Milk. Ames: Iowa State University Press, Iow.

Leng, R A; J H Stambolie and R Bell. 1995. Duckweed - a potential highprotein feed resource for domestic animals and fish Centre for Duckweed Research $\mathcal{E}$ Development University of New England Armidale, NSW 2351Livestock Research for Rural
Development Volume 7, Number 1, October 1995.

Nopriani U, PDMH Karti, dan I Prihantoro. 2014. Produktivitas duckweed (Lemna sp. minor) sebagai hijauan pakan alternatif ternak pada intensitas cahaya yang berbeda. JITV 19(4): 272-286.

DOI:http://dx.doi.org/10.14334/jitv.v19 i4.1095.

Nurtini S, Yustina YS. 2007. Penampilan Usaha Sapi Perah Dengan Menggunakan Pakan Jerami Fermentasi (Performance of Dairy Cattle Production Fed with Fermented Rice Straw). Di dalam: Prospek Industri Sapi Perah Menuju Perdagangan Bebas 2020. Prosiding Semiloka Nasional; Jakarta, 21 April 2008. Jakarta: Pusat Penelitian dan Pengembangan Peternakan Bekerjasama dengan Sekolah Tinggi Ilmu Ekonomi Keuangan dan Perbankan Indonesia; 2008. hlm 420-424.

Owen, J.B., 1979. Complete Diets For Cattle and Sheep1st edition. Farming Press ltd. Suffolk.

Pelczar dan Chan. 1986. Dasar-Dasar Mikrobiologi Jilid I, diterjemahkan oleh Ratna Siri Hadioetomo, Teja Imas, S. Sutami, Sri Lestari, Universitas Indonesia, Jakarta, 116-117.

Riski. 2016. Pengaruh Penambahan Pelepah Daun Sawit Terhadap Produksi Susu FH.Universitas Hassanudin, Makkasar, Sulawesi Selatan. 
Sidik, R. 2003. Estimasi kebutuhan net energi laktasi sapi perah produktif yang diberi pakan komplit vetunair. Media Kedokteran Hewan. 19 (3) :135-138.

Schmidt, G.H., L.D. Van Vleck and M.F. Hutjunes. 1988. Principles of Dairy Sciences. 2 nd ed. Prentice Hill, Engglewood Cliffs, New Jersey.

Standar Nasional Indonesia. 1998. Standar Mutu Susu Segar No. 013141-1998. Departemen Pertanian. Jakarta.

Soeharsono, 1996. Fisiologi Laktasi. Universitas Padjajaran, Bandung.

Sudono, A. 1999. Ilmu Produksi ternak Perah. Jurusan Ilmu Produksi ternak. Fakultas Peternakan. Institut Pertanian Bogor. Bogor

Sulaeman, E., D.S. Tasripin., dan U. H. Tanuwiria. 2014. Pengaruh Pemberian Silase Biomassa Jagung terhadap Produksi Susu dan Produksi 4\% FCM Pada Sapi Perah. Fakultas Peternakan Universitas Padjadjaran.

Sukarini, I.A.M. 2006. Produksi dan komposisi air susu Kambing Peranakan Etawah yang diberi tambahan konsentrat pada awal laktasi. Majalah Ilmiah Petern. 9:14-25.

Sutama, I K. 1994. Puberty and early reproductive performance of "peranakan etawah" goat. p. 233234. Proc.7th AAAP Animal Science Congress, Bali-Indonesia, 11-16 July 1994.
Widyabroto, B. P. 1996. Degradasi Protein dalam Rumen dan Kecernaan Protein dalam Intestinum. Kursus Singkat Evaluasi Pakan Ruminansia. Fakultas Peternakan. Universitas Gajah Mada, Yogyakarta.

Winarno, F.G. 2008. Kimia Pangan dan Gizi: Edisi Terbaru. Jakarta. Gramedia Pustaka Utama.

Yusuf, R. 2010. Kandungan Protein Susu Sapi Perah Friesien Holstein Akibat Pemberian Pakan yang Mengandung Tepung Katuk yang Berbeda. J. Pet. Fakuktas Pertanian, Universitas Udayana, Samarinda. 